\title{
О ПАРАМЕТРАХ НЕСТАЦИОНАРНОИ ФИЛЬТРАЦИИ ВОДОВМЕЩАЮЩИХ СЛОЕВ В ЭСТОНИИ
}

В 1967-1970 гг. Управлением гидрометеорологической службы Эстонской ССР осуществлена под руководством Т. Эйпре серия наблюдений над колебаниями уровня воды в бытовых колодцах. Колодцы глубиной 2-10 м расположены при гидрологических речных и озерных постах (Ресурсы поверхностных вод СССР, 1972) на расстоянии $12-900$ м от поверхностного водоема. Аналогичные наблюдения проведены также

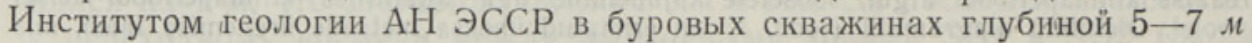
у гидрологического поста оз. Юлемисте и Государственным проектным институтом «Эстпромпроект» в районе морского поста в устье р. Пярну. На основе данных, полученных с участков наблюдений (рисунок), нами определена уровнепроводность верхних водовмещающих слоев (таблица).

Расчеты проводились согласно зависимости (Шестаков, 1965)

$$
a=\frac{x^{2}}{4 \lambda^{2} t},
$$

где $a$ - коэффициент уровнепроводности; $x$ - расстояние между сечениями вдоль фильтрационного потока, где замерялось изменение гидравлического напора; $t$ - промежуток времени, на протяжении которого приращение напора происходило практически с постоянной скоростыю; $\lambda$ - аргумент заданной таблично интегральной показательной функции.

В случае применения формулы (1) обычно предполагается, что вдоль потока подземных вод расположены два пьезометра, которые дают сведения о колебаниях напора. Однако в рассматриваемых случаях уровень подземных вод измерялся в общем лишь в одном колодце у поверхностного водоема. Это заставило нас при расчетах допустить, что изменение напора в сечении фильтрационного потока, совпадающем с береговой линией реки или озера, соответствует колебанию их уровня, установленному наблюдениями на гидрологическом посту.

Наиболее пригодными для вычислений по формуле (1) оказались промежутки времени длительностью в среднем 6-12 суток в начале весеннего, а иногда и осеннего интенсивного повышения уровня поверхностных вод. На некоторых участках в течение четырехлетнего периода наблюдений удалось выделить лишь один-два интервала, соответствующих требованиям методики расчета. В таких случаях подземные воды подвергаются, очевидно, сильному инфильтрационному питанию, ввиду 


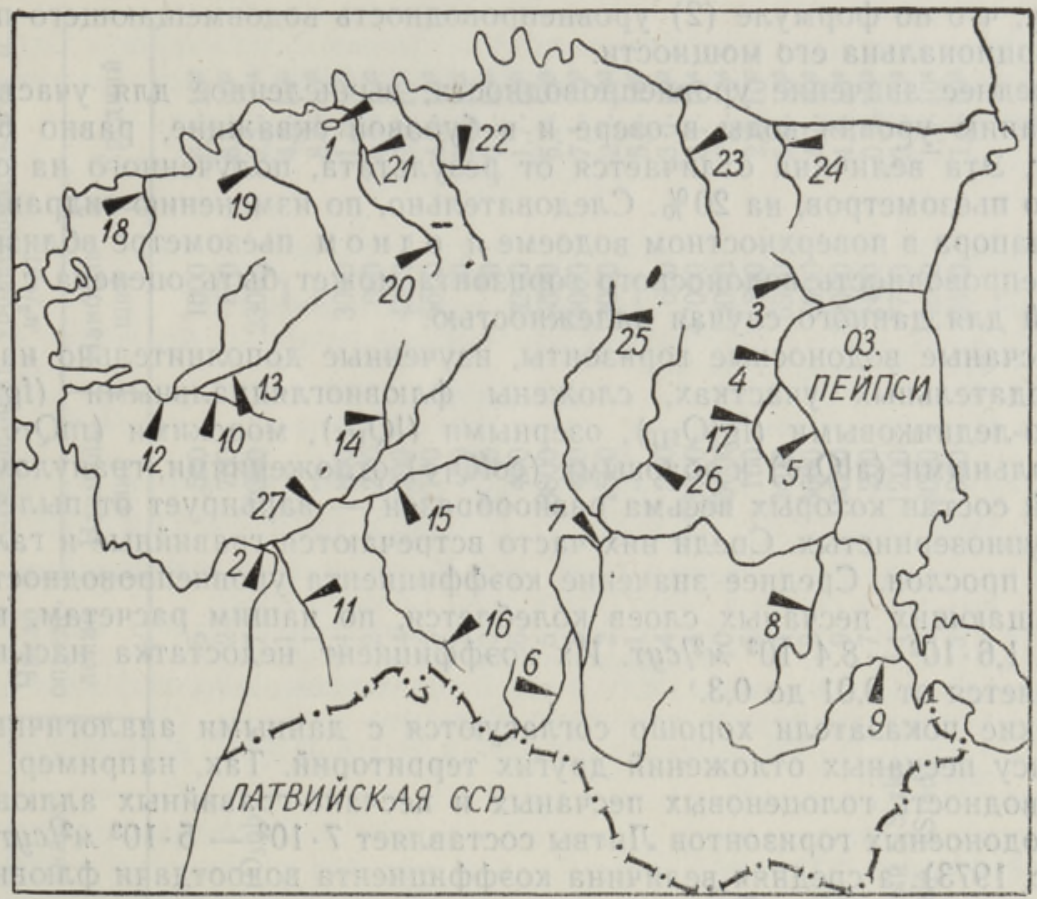

Месторасположение - гидрологических постов (названия пунктов см. в таблице).

которого обусловленность их пьезометрического режима от колебаний уровня поверхностного водоема оказывается скрытой. В таблице по каждому участку указано общее число определений уровнепроводности, приведены расчетные ее максимальное и минимальное значения, а также арифметическое среднее от всех определений.

Наиболее подробно изучены гидрогеологические условия участка, расположенного на северном берегу оз. Юлемисте, где в виде исключения водомерные наблюдения велись в четырех буровых скважинах. Безнапорный водоносный горизонт средней мощностью 8 м сложен здесь флювиогляциальными среднезернистыми песками с гравием и галькой (fglQ $\mathrm{QII}_{\mathrm{I}}$, которые залегают на относительно водоупорном супесчаном слое. Среднее значение коэффициента фильтрации водоносного горизонта составляет $20 \mathrm{M} / \mathrm{cy}$.

Рассчитанный по формуле (1) на основе данных пъезометров коэффициент уровнепроводности флювиогляциальных песчаных отложений составляет в среднем $6,4 \cdot 10^{2} \mathrm{M}^{2} /$ сут. Их коэффициент недостатка насыщения $\mu$ равен 0,25 , причем

$$
\mu=\frac{k h}{a}
$$

где $h-$ средняя мощность водовмещающего слоя и $k-$ его коэффициент фильтрации.

Коэффициенты $a$ и $\mu$ того же водоносного горизонта в 7 км западнее рассматриваемого участка составляют, по данным пробной откачки, соответственно $2000 \mathrm{~s}^{2} /$ сут и 0,3 при мощности горизонта 24 м (Валлнер, 1972). Это практически совпадает с настоящим определением, если иметь 
в виду, что по формуле (2) уровнепроводность водовмещающего пласта пропорциональна его мощности.

Среднее значение уровнепроводности, вычисленное для участка по колебанию уровня воды в озере и в буровой скважине, равно $5,1 \cdot 10^{2}$ $\mathrm{M}^{2} /$ cyт. Эта величина отличается от результата, полученного на основе только пьезометров, на $20 \%$. Следовательно, по изменению гидравлического напора в поверхностном водоеме и одн о м пьезометре вблизи него уровнепроводность водоносного горизонта может быть оценена с достаточной для данного случая надежностью.

Песчаные водоносные горизонты, изученные дополнительно на семи наблюдательных участках, сложены флювиогляциальными (fglQ озерно-ледниковыми $\left(\lg l Q_{\text {III }}\right)$, озерными $\left(1 Q_{\text {III }}\right)$, морскими (mQ $\left.Q_{\text {IV }}\right)$, аллювиальными (alQ IV) и эоловыми (eolQ IV) отложениями, гранулометрический состав которых весьма разнообразен - варьирует от пылеватых до крупнозернистых. Среди них часто встречаются гравийные и галечниковые прослои. Среднее значение коэффициента уровнепроводности водовмешаюших песчаных слоев колеблется, по нашим расчетам, в пределах $1,6 \cdot 10^{2}-8.4 \cdot 10^{3} \mathrm{M}^{2} / c y T$. Их коэффициент недостатка насыщения изменяется от 0,01 до 0,3 .'

Такие показатели хорошо согласуются с данными аналогичных по генезису песчаных отложений других территорий. Так, например, уровнепроводность голоценовых песчаных и песчано-гравийных аллювиальных водоносных горизонтов Литвы составляет $7 \cdot 10^{2}-5 \cdot 10^{3} \mathrm{M}^{2} /$ сут (Дилюнас, 1973), а средняя величина коэффициента водоотдачи флювиогляциальных, озерно-ледниковых, морских и аллювиальных слоев изменяется в пределах $0.08-0,33$ (Сакалаускене, 1969). В Белоруссии уровнепроводность водоносных флювиоглящиальных и аллювиальных песчаных отложений различной зернистости, содержащих гравийные и галечниковые прослои, характеризуется величинами порядка $10^{2}-10^{3} \mathrm{M}^{2} /$ cuт . причем значение коэффициента водоотдачи колеблется от 0,035 до 0,26 (Киселев, 1964, 1967; Козлов, Шилинская, 1972).

На восьми наблюдательных участках безнапорные воды вмещаются в переслаивающихся супесчаных, суглинистых и песяаных отложениях преимущественно озерного ( $1 \mathrm{Q}_{\mathrm{III}}$ ) или морокого ( $\left.\mathrm{MQ}_{\mathrm{IV}}\right)$ происхождения. Если среди них преобладает песчаный материал. то уровнепроводность водоносного горизонта изменяется в интервале $3 \cdot 10^{2}-7 \cdot 10^{3} \mathrm{M}^{2} /$ сут, а коэффициент недостатка насыщения составляет $0,01-0,07$. При увеличении относительной доли суглинистых прослоев в горизонте его уровнепроводность сильно понижается (Вянгла, Сурью). Коэффициент недостатка насыщения в таком случае обычно меньше 0,01 .

В северной и средней частях Эстонии безнапорные воды часто связаны с первыми от поверхности слоями известняков и доломитов ордовикской и силурийской систем, а также с залегающим над ними маломощным пластом супесчаной морены (glQшi). Уровнепроводность такой водовмещающей толщи, суммарная мощность которой обычно не превышает 30 м, колеблется, по нашим расчетам, в интервале $0,9 \cdot 10^{3}-5,1$. $10^{3} \mathrm{M}^{2} /$ сут. Она может достигать и величин порядка $10^{4} \mathrm{M}^{2} / c y T$, если водоносные карбонатные породы сильно закарстованы и трещиноваты. Коэффициент насыщения рассматриваемых пород имеет, по нашим определениям, порядок величины $10^{-2}$. Это согласуется с установленной по другой методике активной скважностью ордовикских слоев, равной 0,021 и акцептованной в исследовании М. С. Газизова (1971).

Уровнепроводность приповерхностных слоев песчаников среднего девона $\left(\mathrm{D}_{2} \mathrm{pr}\right)$ изучена только в одном месте - Орекюла. Она составляет там примерно $2 \cdot 10^{3} \mu^{2} /$ cyT. 


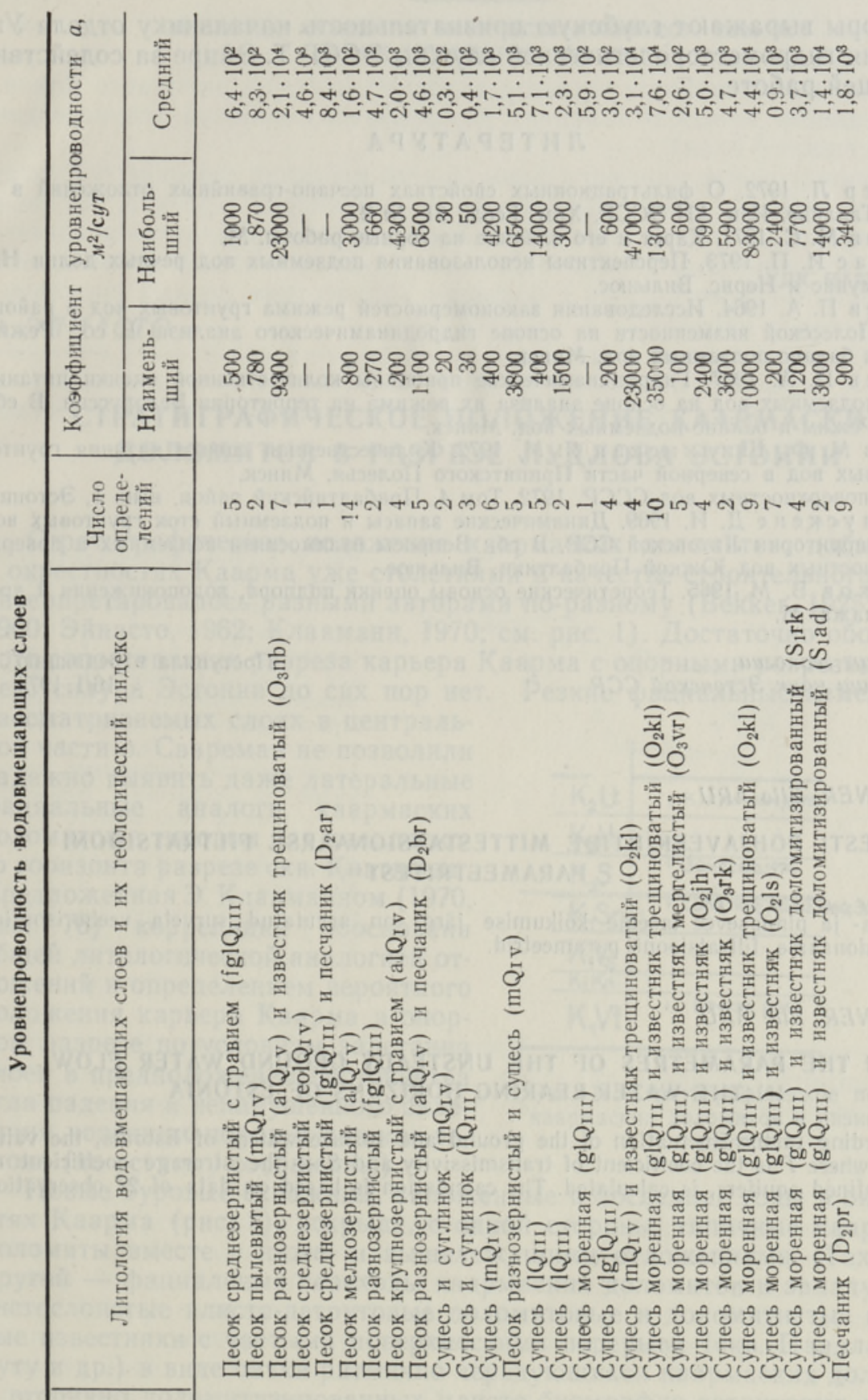

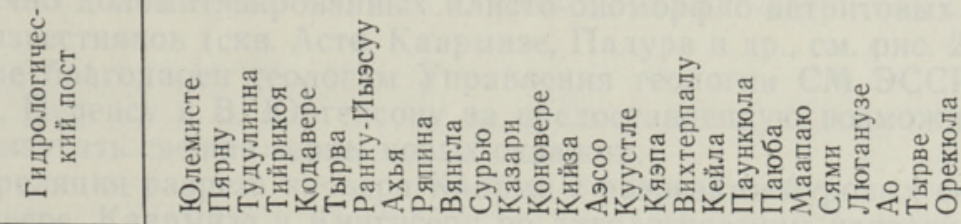


Авторы выражают глубокую признательность начальнику отдела Управления гидрометеорологической службы ӘССР Т. Эйпре за содействие настоящей работе.

\section{ЛИТЕРАТУРА}

В а л л н е р Л. 1972. О фильтрационных свойствах песчано-гравийных отложений в $r$. Таллине. Изв. АН ЭССР, Хим. Геол., 21, № 2.

Г а з и з о в М. С. 1971. Карст и его влияние на горные работы. М.

Д и лю н а с И. П. 1973. Перспективы использования подземных вод речных долин Нямунас и Нерис. Вильнюс.

К и селе в П. А. 1964. Исследования закономерностей режима грунтовых вод в районе Полесской низменности на основе гидродинамического анализа. В сб.: Режим и баланс подземных вод. Минск.

К и селев П. А. 1967. Гидродинамические принципы количественной оценки питания подземных вод на основе анализа их режима на территории Белоруссии. В сб.: Режим и баланс подземных вод. Минск.

Козлов М. Ф., Ши лин ск а я Я. М. 1972. Количественная оценка питания грунтовых вод в северной части Припятского Полесья. Минск.

Ресурсы поверхностных вод СССР. 1972. Том 4, Прибалтийский район, вып. 1, Эстония.

С а к а л а ускен е Д. И. 1969. Динамические запасы и подземный сток грунтовых вод территории Литовской ССР. В сб.: Вопросы взаимосвязи подземных и поверхностных вод Южной Прибалтики. Вильнюс.

Ш е с т а ко в В. М. 1965. Теоретические основы оценки подпора, водопонижения и дренажа. M.

Ннститут геологии

Академии наук Эстонской ССР

Поступила в редакцию

$16 / \mathrm{I} 1974$

\section{VALLNER, Elle ARU}

\section{EESTI PÕHJAVEEKIHTIDE MITTESTATSIONAARSE FILTRATSIOONI PARAMEETRITEST}

Põhja- ja pinnasevee taseme kõikumise järgi on arvutatud surveta veehorisontide mittestatsionaarse filtratsiooni parameetrid.

\section{VALLNER, Elle ARU}

\section{ON THE PARAMETRES OF THE UNSTEADY GROUND WATER FLOW IN THE WATER-BEARING HORIZONS OF ESTONIA}

According to the fluctuation of the ground and surface waters of Estonia, the value $a=T / S$, where $T$ is the coefficient of transmissivity and $S$ - the strorage coefficient of the unconfined aquifers, is calculated. The calculation is based on data of 27 observation districts. 